Review

\title{
Good Cop, Bad Cop: The Opposing Effects of Macrophage Activation State on Maintaining or Damaging Functional $\beta$-Cell Mass
}

\author{
Daelin M. Jensen, Kyle V. Hendricks, Austin T. Mason and Jeffery S. Tessem * (D) \\ Nutrition, Dietetics and Food Science Department, Brigham Young University, Provo, UT 84602, USA; \\ daelinmichael@gmail.com (D.M.J.); kylev.hendricks@gmail.com (K.V.H.); \\ austintaylormason@gmail.com (A.T.M.) \\ * Correspondence: Jeffery_tessem@byu.edu
}

Received: 20 October 2020; Accepted: 24 November 2020; Published: 26 November 2020

check for updates

\begin{abstract}
Loss of functional $\beta$-cell mass is a hallmark of Type 1 and Type 2 Diabetes. Macrophages play an integral role in the maintenance or destruction of pancreatic $\beta$-cells. The effect of the macrophage $\beta$-cell interaction is dependent on the activation state of the macrophage. Macrophages can be activated across a spectrum, from pro-inflammatory to anti-inflammatory and tissue remodeling. The factors secreted by these differentially activated macrophages and their effect on $\beta$-cells define the effect on functional $\beta$-cell mass. In this review, the spectrum of macrophage activation is discussed, as are the positive and negative effects on $\beta$-cell survival, expansion, and function as well as the defined factors released from macrophages that impinge on functional $\beta$-cell mass.
\end{abstract}

Keywords: $\beta$-cell; macrophage; islet; cytokine; diabetes

\section{Introduction}

The prevalence of diabetes is growing. It is currently estimated that 463 million individuals are diabetic and that by the year 2045 that number will increase to 700 million [1]. While the etiologies of the two primary forms of diabetes are clearly different, Type 1 Diabetes (T1D) and Type 2 Diabetes (T2D) both result in decreased functional $\beta$-cell mass (defined as changes in $\beta$-cell survival, proliferation, and insulin secretion). T1D is characterized by autoimmune destruction of the insulin-producing pancreatic $\beta$-cells [2], and T2D is characterized by $\beta$-cell dysfunction and the ultimate loss of $\beta$-cell maturity and increased $\beta$-cell death [3].

While clearly observed with T1D, the increased presence and islet infiltration of hematopoietic cells are also observed in the pancreas of T2D patients [4,5]. Additionally, resident monocyte-derived dendritic cells and macrophages also play a critical role in $\beta$-cell homeostasis [6]. Signaling from these cell types can result in modifications in $\beta$-cell function, survival, and proliferation. The direct interaction between hematopoietic cells and $\beta$-cells plays a critical role in the maintenance of functional $\beta$-cell mass.

Resident macrophages are found in all human tissues. The entire macrophage pool in an adult human is estimated to be about $10^{10}$ cells [7]. Macrophages are a critical part of the innate immune response that specializes in the detection and destruction of foreign pathogens as well as the activation and recruitment of adaptive immune cells. Inflammatory macrophages have classically been considered to be detrimental to $\beta$-cell function and survival, thereby contributing to $\beta$-cell failure in both T1D and T2D. Recent findings, however, have demonstrated that anti-inflammatory macrophages play a supportive role through tissue remodeling that protects $\beta$-cells and enhances insulin secretion and replication. These contradictory effects of the macrophage on the $\beta$-cell are due to the macrophage 
activation state and the factors that are produced by and released from macrophages found in the pancreatic islet. In this review, the deleterious and protective effects of macrophages on the $\beta$-cell are described in the context of macrophage activation states and the factors secreted by macrophages that signal to the $\beta$-cell. Further understanding of the origins and activation pathways of tissue-resident macrophages is fundamental for the design of intervention strategies to maintain functional $\beta$-cell mass as a treatment for T1D and T2D.

\section{The Macrophage Activation Spectrum}

Macrophages play an important role in maintaining tissue homeostasis, completing essential tissue-specific functions, and protecting the organism from infection. Due to the presence of scavenger receptors, they are able to perform housekeeping tasks such as removal of aged red blood cells, necrotic tissue, and toxic molecules, in the absence of special activation-associated stimuli. However, under the distress of infected or injured tissue, these homeostatic functions are increased by a variety of activating stimuli [8].

Tissue-resident macrophages were thought to continuously repopulate from circulating monocytes, which are ontologically derived from hematopoietic stem cells [9]. Recent studies have challenged this view. Although monocytes have the ability to differentiate into macrophages, subpopulations of resident macrophages in certain tissues (such as the pancreas) result from yolk-sac derived precursors during embryonic development $[10,11]$. This suggests that the pancreatic macrophage population is able to be maintained independently of circulating monocytes [12].

Macrophages are traditionally divided into two functional subgroups; the classically activated, inflammatory and cytotoxic M1-like macrophages and the alternatively activated M2-like macrophages that are anti-inflammatory and mediate tissue repair and remodeling [10]. It is now understood that these subsets better represent different points on a spectrum of macrophage activation states [13] and that other activation states may well be present [14]. Macrophages are able to respond to specific environmental signals to express various activation states along a dynamic range of phenotypes [15]. Nevertheless, for the sake of simplicity, we will use the subgroups M1-like and M2-like macrophage designations (Figure 1).

M1-like macrophages are characterized by their immunogenic properties. These properties protect against infection by propagating proinflammatory responses [16]. In the case of obesity-related pancreatic inflammation that is common in T2D, an abundance of free fatty acids (FFA), reactive oxygen species (ROS), islet amyloid polypeptide (IAPP), and proinflammatory cytokines increase M1-like macrophage polarization [17]. An M1-like macrophage can further propagate this response through the activation of the non-obese diabetic (NOD)-, LRR- and pyrin domain containing 3 (NLRP3) inflammasome. Once activated, the NLRP3 inflammasome secretes cytokines such as interleukin-1 beta (IL-1 $\beta$ ) that induce M1-like polarization of other macrophages [18]. The proinflammatory M1-like state is also enhanced in the presence of interferon-gamma (IFN- $\gamma$ ), lipopolysaccharide (LPS), IL-1 $\beta$, and tumor necrosis factor-alpha $(\mathrm{TNF} \alpha)$. Additionally, M1-like macrophages are efficient producers of effector molecules such as ROS and reactive nitrogen species (NOS). They also produce inflammatory cytokines, such as IL-1 $\beta$, IL-6, IL-12, and TNF- $\alpha$, and chemokines such as chemokine (C-X-C motif) ligand 9 (CXCL9), CXCL10, and Chemokine (C-C motif) ligand 5 (CCL5). Additionally, M1-like macrophages express major histocompatibility complex (MHC) class II. These factors allow the M1-like macrophage to be recognized by and induce an immune response from T helper 1 (Th1) cells [19].

The M2-like macrophage primarily serves an anti-inflammatory and tissue regenerative purpose. M2-like macrophage polarization has a wider variety of activating stimuli. Anti-inflammatory signals such as IL-4, IL-13, macrophage colony-stimulating factor (CSF-1), and transforming growth factor beta (TGF- $\beta$ ) are associated with differentiation to the M2-like tissue regenerative and remodeling phenotype [20]. IL-4 and IL-13 were among the first to be discovered as inhibitors of the classical M1-like phenotype [16]. IL-21 is another important cytokine that drives M2-like polarization. Additionally, IL-33 is a cytokine of the IL-1 family that amplifies IL-13-induced polarization of macrophages to the 
M2-like phenotype. The M2-like phenotypes are characterized by the expression of chitinase 3 like 1 (CHI3L1), CCL24, CCL17, and arginase 1. M1-like macrophages metabolize arginine through NOS2 to produce nitric oxide (NO), M2-like macrophages use arginase 1 (ARG1) to metabolize arginine into polyamines that are used for proliferation and tissue remodeling [16]. M2-like macrophages express Th2 attracting chemokines CCL17 and CCL24, allowing the M2-like macrophages to work synergistically with Th2 cells to resolve inflammation and promote tissue remodeling, angiogenesis, and immunoregulation. Even within the M2-like "classification" there appear to be M2-like subtypes based on in vitro activation studies, expression profile, and function. M2a macrophages are activated by IL-4 and IL-13, express scavenger and phagocytic receptors, and secrete fibronectin, insulin-like growth factor (IGF), and TGF $\beta$. M2b macrophages produce the proinflammatory IL-1 $\beta$, IL- 6 , and TNF- $\alpha$, and the anti-inflammatory IL-10. M2b cells are activated by Toll-like receptors and IL-1 receptor antagonists. M2c macrophages are activated through IL-10 and glucocorticoids. They remove apoptotic cells through expression of tyrosine-protein kinase MER (MerTK). Finally, M2d macrophages express IL-10 and vascular endothelial growth factor (VEGF). This wide variety of "M2" macrophage subtypes emphasizes the current understanding that M1-like and M2-like macrophages define extremes of a "macrophage activation spectrum" in terms of activation, gene expression, and function [21-24].

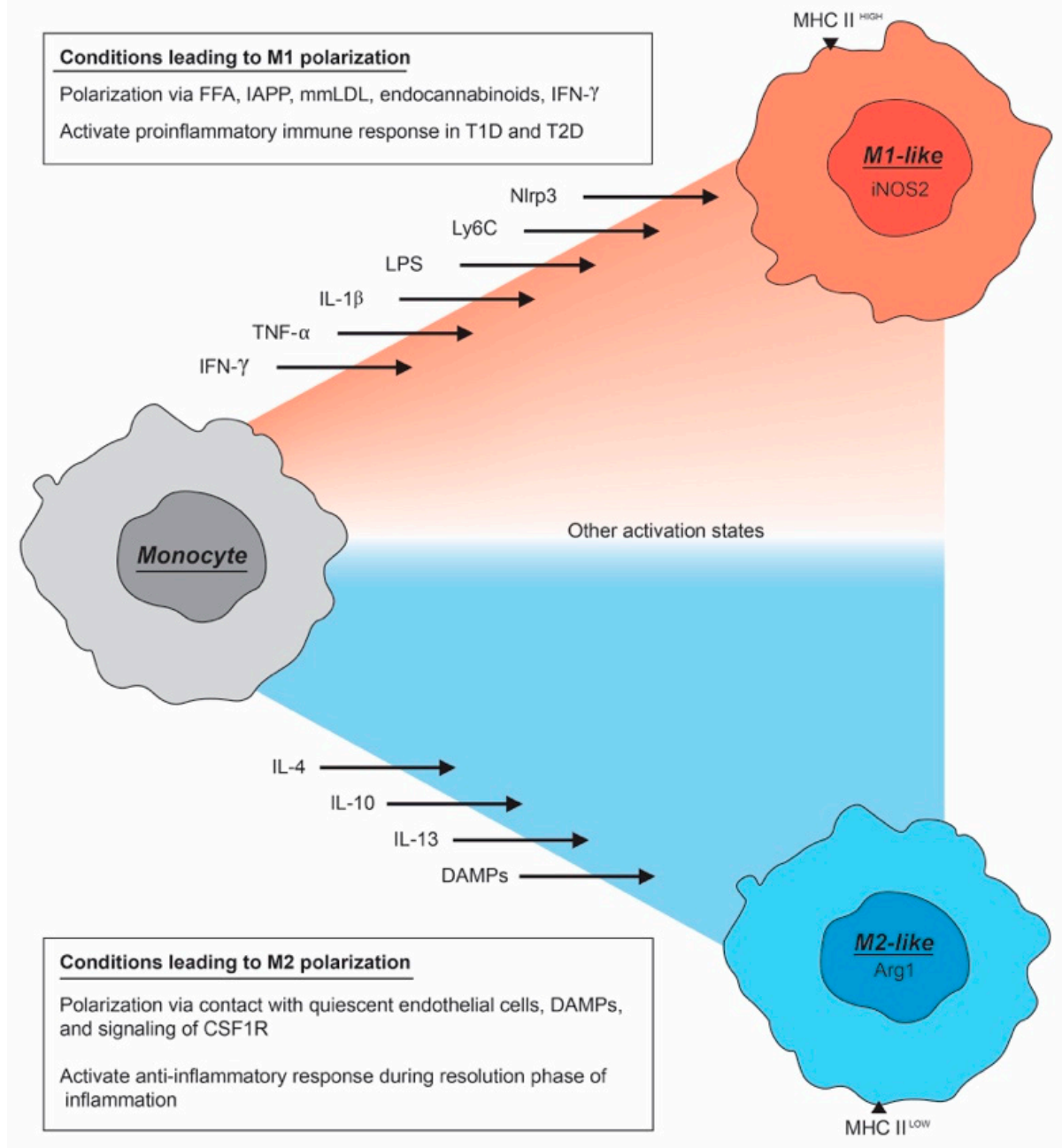

Figure 1. Polarization of monocytes to M1-like or M2-like macrophages. Macrophages can be polarized along an activation spectrum in response to different signals within their microenvironment. An undifferentiated macrophage will lean more M1-like under proinflammatory conditions, propagating a "kill" response. Conversely, a macrophage may lean more M2-like under anti-inflammatory conditions usually following M1 damage where a "heal" response is necessary. 


\section{Macrophages Can Impair $\beta$-Cell Function and Survival}

Extensive findings demonstrate that M1-like macrophages have deleterious effects on $\beta$-cells by impairing glucose-stimulated insulin secretion (GSIS), inducing apoptosis, and causing $\beta$-cell dedifferentiation. NOD mice that spontaneously develop T1D, can have diabetes development impaired through macrophage depletion [25]. These findings have been substantiated in the BioBreeding Diabetes Prone rat (DP-BB) model [26]. Similarly, human tissue sections from T1D patients demonstrate macrophage infiltration of the islet $[27,28]$. The key proinflammatory cytokines observed in T1D are TNF- $\alpha$, IL-1 $\beta$, and IFN- $\gamma$, all of which are produced by macrophages [29]. Macrophages isolated from T1D patients have elevated proinflammatory gene expression. Interestingly, macrophages from long-term T1D patients have an impaired ability to undergo M2-like activation, suggesting potential changes to the macrophage population over time [30]. Macrophages exposed to oxidative stress produced elevated ROS levels that can push the macrophage toward an M1-like phenotype, which can be reverted to an M2-like phenotype with the use of ROS scavengers [31,32].

Islet inflammation is also a characteristic of T2D. Increased macrophage numbers have been observed in human T2D pancreata as well as rodent T2D models such as $\mathrm{db} / \mathrm{db}$ mice, GK rats, and diet-induced obesity models [18,33-39]. Islets from T2D patients have elevated IL-6, IL-8, CXCL1, granulocyte colony-stimulating factor (GCSF), and macrophage inflammatory protein-1 alpha (MIP1 $\alpha$ ) levels [33]. Hyperglycemia and hyperlipidemia induce islet chemokine secretion which results in macrophage islet infiltration. These macrophages express M1-like markers, and depletion of M1-like macrophages suppresses $\beta$-cell lipotoxicity in vivo $[9,36]$. Various systemic changes associated with obesity can induce macrophage activation to an M1-like phenotype, and result in increased secretion of inflammatory cytokines such as IL-1 $\beta$, IFN- $\gamma$, and TNF- $\alpha$ that directly signal to and affect $\beta$-cell function and survival [40]. Using clodronate-mediated macrophage suppression, $\mathrm{db} / \mathrm{db}$ and KKAy mice have improved glucose tolerance and insulin secretion, demonstrating that macrophages in these T2D models impair $\beta$-cell function [36]. $\beta$-cell dedifferentiation is a hallmark of T2D and plays a major role in decreasing functional $\beta$-cell mass [41]. $\mathrm{Db} / \mathrm{db}$ islets have impaired expression of $\beta$-cell identity genes, such as MAF BZIP Transcription Factor A (MafA), pancreatic and duodenal homeobox 1 (Pdx1), Glut2, and potassium inwardly rectifying channel subfamily J member 11 (Kcnj11). Interestingly, $\beta$-cell identity gene expression improves when macrophages are depleted from $\mathrm{db} / \mathrm{db}$ islets [42]. These results demonstrate that M1-like macrophages have a deleterious effect on functional $\beta$-cell mass in T1D and T2D.

\section{Macrophage Produced Secreted Factors That Negatively Modulate Functional $\beta$-Cell Mass}

The primary cytokines produced by macrophages that negatively impact functional $\beta$-cell mass are IL-1 $\beta$, IL-6, IFN- $\gamma$, and TNF- $\alpha$ (Table 1). These cytokines have negative effects on functional $\beta$-cell mass by impairing GSIS, inducing cell death, and increasing $\beta$-cell dedifferentiation. IL- $1 \beta$ is a member of the interleukin 1 (IL-1) family of cytokines. As such, IL-1 $\beta$ is involved early in the immune response to signal the production of other cytokines. Although the islet is capable of producing IL- $1 \beta$ under diabetogenic conditions, mouse and human islet studies have shown that macrophages secrete the overwhelming majority of IL-1 $\beta$ [43]. Additionally, $\beta$-cells express high levels of interleukin-1 receptor (IL-1R), and as such are highly sensitive to IL-1 $\beta$ [44]. It has been shown that when $\beta$-cells are subject to acute exposure of IL-1 $\beta$, GSIS and overall $\beta$-cell survival improve. However, numerous studies have shown that chronic exposure to IL-1 $\beta$ common to diabetogenic or obese conditions causes impaired GSIS and increased $\beta$-cell de-differentiation and death $[43,45,46]$. Blocking IL-1 $\beta$ or inhibiting IL-1R results in improved outcomes in the restoration of $\beta$-cell function, mass, and the reversal of T2D phenotypes $[9,47,48]$.

IL-1 $\beta$ signaling results in activation of nuclear factor kappa-light-chain-enhancer of activated $B$ cells (NF-KB) and mitogen-activated protein kinase (MAPK) pathways [49], through which the $\beta$-cell releases chemokines such as CXCL1 and CXCL2 to recruit cells of the innate and adaptive immune system. In a study using neonatal NOD mice, those treated with a neutralizing anti-IL-1 $\beta$ 
monoclonal antibody (mAb) had decreased macrophage and neutrophil islet infiltration [50]. Similarly, mice treated with anti-IL-1 $\beta \mathrm{mAb}$ demonstrated a significant decrease in islet produced CXCL1 and CXCL2, which recruits infiltrating immune cells through the CXCR2 receptor [51,52]. The use of IL-1R antagonist drugs has shown significant reductions in islet macrophage infiltration [53]. Finally, $\beta$-cells exposed to IL- $1 \beta$ increase expression and secretion of other proinflammatory signals monocyte chemoattractant protein-1 (MCP-1), IL-6, and TNF- $\alpha$, thus inducing greater macrophage migration and islet inflammation [18]. The combined exposure of islets to IL-1 $\beta$ and IL-6 decreases GSIS, increases endoplasmic reticulum (ER) stress marker expression (such as Inducible nitric oxide synthase 2 (iNOS2), activating transcription factor 4 (ATF4), and CCAAT/enhancer binding protein (C/EBP) homologous protein (CHOP)), induces calcium handling deficiencies, and increases cell death [54]. These data demonstrate the IL-1 $\beta$ signaling at the $\beta$-cell results in the production of signals to enhance islet inflammation.

Culturing macrophages ex vivo with elevated glucose or fatty acids induces IL-1 $\beta$ release $[47,55]$. Min6 $\beta$-cells cultured with conditioned media from palmitate-treated macrophages demonstrated that preclearing the media with neutralizing antibodies blocked the effect of these cytokines to impair $\beta$-cell function [36]. Macrophages cultured with Min6 $\beta$-cells result in increased cytokine secretion, which impedes GSIS, and the addition of anti-IL-1 $\beta$ and anti-TNF- $\alpha$ antibodies improves GSIS [36]. $\beta$-cell IL-1 $\beta$ signaling through the MAPK and c-Jun N-terminal kinase (JNK) pathway results in downregulation of the phosphatidylinositol 3-kinase-protein kinase B signaling pathway (P13K-AKT) signaling cascade, and ultimately decreases PDX1-mediated gene expression $[45,56]$. This results in a decrease in insulin mRNA levels and impaired GSIS [57-63].

IL-1 $\beta$ induces pro-apoptotic and necrotic pathways in the $\beta$-cell through the extracellular signal-regulated kinase (ERK) signaling pathways [64]. ER stress that is characteristic of T2D $\beta$-cells potentiates the IL-1 $\beta$ signaling pathway and leaves the $\beta$-cell more susceptible to IL-1 $\beta$-mediated cell death [54]. TNF- $\alpha$ and IFN- $\gamma$ work synergistically with IL-1 $\beta$ to induce $\beta$-cell apoptosis via the intrinsic and extrinsic apoptotic pathways. IL- $1 \beta$ and IFN- $\gamma$ induce the intrinsic apoptotic pathway through the activation of the NF- $\mathrm{kB}$-mediated gene network. NF- $\mathrm{kB}$ activation subsequently leads to NO and cytokine production, depletion of ER calcium stores, and induction of ER stress. Rat islets cultured with IL-1 $\beta$ and IFN- $\gamma$ revealed expression changes to genes associated with inflammation, cell death, antigen presentation, and cytokines/chemokine production [65]. ER stress results in mitochondrial damage, cytochrome c release, and mitochondrial death signals that activate caspase 9 and caspase 3 resulting in activation of the intrinsic apoptosis pathway $[66,67]$. Human islets cultured with TNF- $\alpha$, IFN- $\gamma$, and IL-1 $\beta$ with or without NO induced ER stress as indicated by increased expression of CHOP, activating transcription factor 3 (ATF3), binding immunoglobulin protein (BIP), and X-box binding protein-1 (XBP1). IL-1 $\beta$ can also induce apoptosis via the extrinsic pathway by up-regulating Fas receptor expression [68].

IL-1 $\beta$ can induce $\beta$-cell dedifferentiation. Human and rodent islets cultured with IL-1 $\beta$, IL-6, and TNF- $\alpha$ present with $\beta$-cell dedifferentiation [69]. Furthermore, IL-1 $\beta$ induces downregulation of forkhead box protein O1 (Foxo1), which is essential for maintaining $\beta$-cell differentiation. Similar results are observed with EndoC- $\beta \mathrm{H} 1$ and human islets, where culture with the same mixture of cytokines induces upregulation of progenitor genes such as SRY-Box Transcription Factor 9 (Sox9), and downregulation of mature $\beta$-cell genes [70]. Interestingly, culturing $\beta$-cells with non-cytotoxic IL-1 $\beta$ levels impaired insulin secretion, reduced $\beta$-cell proliferation, and decreased expression of $\beta$-cell identity genes such as MafA and Urocortin-3 (Ucn3) [71]. These changes, however, were reversible as IL-1 $\beta$ removal restored $\beta$-cell identity gene expression. While these data strongly suggest that IL-1 $\beta$ plays a critical role in inducing $\beta$-cell dedifferentiation, pancreatic IL-1R deletion (the receptor by which IL-1 $\beta$ signal transduction occurs) also results in impaired $\beta$-cell function and increased expression of the dedifferentiation marker Aldh1a3 [45]. More studies will need to be completed to clearly understand the role of IL- $1 \beta$ on $\beta$-cell dedifferentiation. 
One of the key differences between M1-like and M2-like macrophages is arginine metabolism. M1-like macrophages use arginine to produce NO by way of iNOS2. Macrophage production of $\mathrm{NO}$ and ROS have direct effects on functional $\beta$-cell mass due to low $\beta$-cell expression of radical scavenging pathways. NF- $\mathrm{B}$ regulates the expression of inducible nitric oxide synthase (iNOS) in $\beta$-cells, with many of the gene expression changes associated with cytokine exposure being secondary to iNOS-mediated NO formation. Increased macrophage produced NO and ROS leads to DNA damage and activation of poly (ADP-ribose) polymerase (PARP) to facilitate DNA repair. PARP activation depletes the $\beta$-cells NAD pool, which can lead to $\beta$-cell necrosis [72]. IL-1 $\beta$ stimulates $\beta$-cell iNOS expression, which leads to elevated internal NO levels. Increased cellular NO impairs electron transfer, decreases mitochondrial ATP production, and induces the expression of proinflammatory genes in the $\beta$-cell [73].

IL-6 signals through the IL-6 receptor system. This results in signal transducer and activator of transcription 3 (STAT3) activation and MAPK activation and increased transcription of downstream target genes [74,75]. IL-6 is sufficient to impair GSIS and decrease islet insulin content [76,77]. Conversely, chemically inhibiting IL-6 signaling at the IL-6 receptor improves insulin content and GSIS [78]. The observed decrease in insulin content due to IL-6 is due to transcriptional changes, as IL-6 decreases Ins1, Ins2, and PDX1 mRNA levels [79]. IL-6 signaling may also impair mitochondrial function through inducing mitochondrial fission and potentially increased mitophagy [80].

IFN- $\gamma$ is a pro-inflammatory cytokine responsible for $\beta$-cell destruction. IFN- $\gamma$ signals to the $\beta$-cell through the interferon-gamma receptor (IFNGR) complex. This receptor complex activates the JAK/STAT and the NF- $\kappa B$ signaling cascades $[49,81]$. This leads to activation of the transcription factor interferon regulatory factor 1 (IRF-1) and upregulation of caspase-1, caspase-3, caspase-9 [82], and other proapoptotic gene expression [82]. Loss of STAT1 signaling impairs IFN- $\gamma$-mediated cell death [83]. Furthermore, loss of STAT1 impairs IP-10 and iNOS gene expression [83]. IFN- $\gamma$ also impairs $\beta$-cells insulin content and GSIS $[84,85]$. Finally, IFN- $\gamma$ potentiates IL-1 $\beta$-mediated iNOS expression and NO production in the $\beta$-cell [86-88].

TNF- $\alpha$ was originally thought to be produced by T-cells, however, data demonstrate that TNF- $\alpha$ is primarily produced by macrophages and dendritic cells in the islet $[89,90]$. TNF- $\alpha$ signals through the TNFR and activates the NF- $\mathrm{KB}$ and MAPK signaling cascades $[49,91]$. Once a threshold of activation through NF- $\kappa B$ is activated, proapoptotic and inflammatory pathways are activated [92]. Inhibition of TNF- $\alpha$, NF- $\kappa B$, and JNK has been shown to improve $\beta$-cell survival and function [93]. These signaling cascades can lead to $\beta$-cell dysfunction and death [93]. TNF- $\alpha$, IL-1 $\beta$, and IFN- $\gamma$ all induce ROS production in $\beta$-cells through activation of nicotinamide adenine dinucleotide phosphate (NADPH) oxidases [94]. They also upregulate iNOS expression, resulting in increased NO production [95,96]. Increased ROS and NO production results in mitochondrial damage and activation of the intrinsic apoptotic pathway [97]. Induction of iNOS through the TNF- $\alpha$ signaling cascade functions through the IRF transcription factor $[98,99]$. Human islets exposed to TNF- $\alpha$, IL-1- $\beta$, and IFN- $\gamma$ have increased expression of various cytokines that enhance immune cell migration, including CXCL1, CXCL8, CCL20, CCL2, and CXCL10 through the NF- $\kappa$ B and STAT1 signaling cascade [100]. TNF- $\alpha$ also induces $\beta$-cell $\mathrm{Ca}^{2+}$ influx, which can negatively affect insulin secretion and $\beta$-cell survival [101]. Finally, using a TNF- $\alpha$ antagonist partially restored $\beta$-cell identity gene expression that are lost during dedifferentiation [69]. These data demonstrate the negative effect that these various M1-like macrophages produced secreted factors have on the pancreatic $\beta$-cell. 
Table 1. Macrophages secreted factors that have a negative effect on functional $\beta$-cell mass.

\begin{tabular}{|c|c|}
\hline Effectors & Target \\
\hline IL-1 $\beta$ & $\begin{array}{c}\text { Initiates } \beta \text {-cell apoptosis through ERK signaling pathways }[18,64] \\
\text { Decreases insulin mRNA levels [57-63] } \\
\text { Impairs GSIS [57-63] } \\
\text { Increases IL-6 release in } \beta \text {-cell [18] } \\
\text { Transcriptional changes of } 3068 \text { genes associated with inflammation, cell death, antigen } \\
\text { presentation, and cytokines/chemokines [65] } \\
\text { Contributes to increased ER stress [68] } \\
\text { Increases Fas expression [77] }\end{array}$ \\
\hline IL-6 & $\begin{array}{c}\text { Impairs GSIS [76,77] } \\
\text { Decreases Ins1, Ins2, and PDX1 mRNA levels in the islet [79] }\end{array}$ \\
\hline IFN- $\gamma$ & $\begin{array}{l}\text { Participates with IL-1 } \beta \text { to activate NF- } \mathrm{kB} \text { genes, leading to NO and cytokine production leading to } \\
\text { ER stress [65] } \\
\text { Participates with IL- } 1 \beta \text { to cause transcriptional changes to } 3068 \text { genes associated with } \\
\text { inflammation, cell death, antigen presentation, and cytokines/chemokines [65] } \\
\text { Impairs } \beta \text {-cell insulin secretion }[84,85]\end{array}$ \\
\hline TNF- $\alpha$ & $\begin{array}{c}\text { Contributes to increased ER stress [68] } \\
\text { Participates in NF- } \mathrm{kB} \text { pathway activation [92] } \\
\text { Activates proapoptotic and proinflammatory pathways through NF- } \mathrm{BB}[49,91,93] \\
\text { Increases iNOS and NADPH oxidase activity, leading to increased ROS production and } \\
\text { mitochondrial damage [94-97] } \\
\text { Induces intrinsic apoptosis [97] } \\
\text { Increases the expression of cytokines CXCL1, CXCL8, CCL20, CCL2, and CXCL10, which promote } \\
\text { immune cell infiltration of the islet [100] } \\
\text { Induces Ca }{ }^{2+} \text { influx in } \beta \text {-cells, impairing insulin secretion [101] }\end{array}$ \\
\hline
\end{tabular}

\section{M2-Like Macrophage Can Enhance the Development, Maintenance, and Function of $\beta$-Cells}

There is an intimate relationship between macrophages and the development of pancreatic islets, and specifically $\beta$-cell proliferation and survival. Mature F4/80+ macrophages are found in the pancreatic bud by E14.5 [102]. The presence of these macrophages is directly linked to the expansion of $\beta$-cell number during development. Pancreas explants cultured with exogenous macrophage colony-stimulating factor (M-CSF), which is sufficient to induce macrophage proliferation, results in increased macrophage and $\beta$-cell number more than four-fold over the explants cultured without M-CSF, suggesting a connection between macrophage signaling and $\beta$-cell proliferation [102]. The presence and increased migration of macrophages to the developing pancreas is necessary for the delamination of endocrine cells from the pancreatic ducts and their ultimate migration to nascent islets [103]. Similarly, macrophages are observed in the human pancreas as early as 6 weeks of development, with elevated levels of the cytokine CSF-1 also being detected [104]. As CSF-1 is essential for macrophage differentiation, these data suggest that macrophages are needed for nascent $\beta$-cell expansion. CSF-1-deficient osteopetrotic CSF-1 op/op mice, which have impaired production of myeloid-derived macrophages and dendritic cells, also have decreased $\beta$-cell mass and impaired $\beta$-cell proliferation when compared to CSF-1 op/+ littermates [102,103]. These data demonstrate that macrophages are necessary for $\beta$-cell proliferation during embryonic development. Furthermore, given the function of these macrophages, these data suggest a M2-like phenotype.

While the data for macrophage-mediated $\beta$-cell proliferation during development are strong, there are equally compelling data regarding the effects of the macrophage on $\beta$-cell survival and proliferation during adulthood or during disease states. Mice fed a high-fat diet initially demonstrate increased $\beta$-cell proliferation. This proliferation correlates with increased intra-islet macrophage accumulation, where these macrophages express markers indicative of an M2-like activation state $[105,106]$. In fact, hyperplastic islets observed in diet-induced obesity have greater macrophage concentrations, suggesting that macrophages may be needed to open the extracellular 
matrix and create an expansion niche for the growing islet [33]. These studies are supported by other models that demonstrate the effect of macrophages on the $\beta$-cell. Macrophages with an M1-like expression profile shifted to an M2-like profile in response to diphtheria toxin-mediated $\beta$-cell damage and in correlation with the subsequent $\beta$-cell expansion $[107,108]$. Clodronate-mediated macrophage ablation attenuates $\beta$-cell regeneration, suggesting that macrophages are needed for $\beta$-cell expansion in this model. Similarly, pancreatic ductal ligation-mediated $\beta$-cell regeneration is dependent on M2-like macrophages [109-112]. Using a chronic pancreatitis model of $\beta$-cell loss, it was shown that M2-like activated macrophages were essential for $\beta$-cell proliferation and that transplantation with CSF-1R -/- bone marrow (which has impaired macrophage production) results in lost $\beta$-cell mass [113]. Changes in vascularization were also observed, and given the ability of macrophages to assist in vascular remodeling, some of the $\beta$-cell maintenance and proliferation may be vascular mediated [20]. $\beta$-cell regeneration after VEGF-A-mediated $\beta$-cell loss was shown to be dependent on M2-like macrophages [114,115]. Finally, recent observations demonstrate that human pancreatic donors demonstrated a strong correlation between the presence of M2-like macrophages and increased islet vascularization and $\beta$-cell proliferation marker expression [116]. These data demonstrate a direct connection between M2-like macrophages and the maintenance and expansion of $\beta$-cell mass in various models of $\beta$-cell damage and regeneration.

\section{Macrophage Produced Secreted Factors That Positively Modulate Functional $\beta$-Cell Mass}

M2-like macrophages clearly play a protective role in $\beta$-cells in terms of maintaining and expanding functional $\beta$-cell mass. This protective role is mediated by various factors secreted from the macrophage that directly affect the $\beta$-cell (Table 2). Using a streptozotocin (STZ) model of $\beta$-cell destruction, recruitment of M2-like macrophage to islets was observed. It was shown that these M2-like macrophages produce and release wingless-type MMTV integration site family, member 3A (Wnt3a), which induces the $\mathrm{Wnt} / \beta$-catenin pathway in the $\beta$-cell, which resulted in increased $\beta$-cell proliferation [117]. Similarly, using a diphtheria toxin-induced model of $\beta$-cell injury, M2-like macrophages were shown to induce $\beta$-cell survival and proliferation through macrophage produced Wnt and activation of the $\beta$-cell Wnt/ $\beta$-catenin signaling pathway $[107,118]$.

Resident macrophages can be moved to an M2-like phenotype through IL-33 signaling. In response to islet secreted IL-33 and the change of the macrophage phenotype to an M2-like state, changes in secreted factors are observed. This signaling cascade, also facilitated by IL-13 and CSF-2, induces expression of aldehyde dehydrogenase 1 family, member A2 (Aldh1a2), which produces retinoic acid. Retinoic acid released from resident macrophages (and dendritic cells) results in the induction of retinoic acid receptor beta (RAR $\beta$ ) expression in the $\beta$-cell and increased insulin [119].

Using a partial pancreatic ductal ligation demonstrates additional macrophage secreted factors that affect functional $\beta$-cell mass. M2-like macrophages were shown to migrate in response to ductal ligation and secrete TGF $\beta 1$ and EGF. TGF $\beta 1$ induced $\beta$-cell upregulation of mothers against decapentaplegic homolog 7 (SMAD7) and SMAD2, where SMAD7 is sufficient to induce proliferation and SMAD2 acts as an inhibitor of the SMAD7 proliferation cascade. In addition to secreting TGF $\beta 1$, the M2-like macrophages also secreted EGF. The EGF signaling cascade resulted in inhibition of SMAD2 nuclear localization. This allowed $\beta$-cells to undergo proliferation through upregulation of the cell cycle activators cyclin D1/D2 and nuclear exclusion of the cell cycle inhibitor p27 ${ }^{\mathrm{CDKN} 1 \mathrm{~B}}$ [111]. TGF $\beta$ has also been shown to be essential for proper pancreas development $[120,121]$. Furthermore, knockout of TGF $\beta$ receptor I and II in $\beta$-cells inhibits M2-like macrophages-mediated $\beta$-cell proliferation $[111,121]$.

EGF is not the only growth factor secreted from macrophages that have been shown to have a positive effect on $\beta$-cells. Macrophages from obese mice have been shown to increase $\beta$-cell proliferation. This occurs due to PDGF release from the macrophage and signaling to the $\beta$-cell through platelet-derived growth factor receptor (PDGFR) [122]. Hepatocyte growth factor (HGF) has been shown to push macrophages to an M2-like phenotype [123], and M2-like macrophages are capable of secreting HGF [10]. HGF has been shown to increase $\beta$-cell proliferation and increase insulin secretion, 
as well as induce $\beta$-cell regeneration in a partial pancreatectomy model $[124,125]$. IGF-1 produced from M-2 like macrophages has been shown to play a critical role in maintaining functional $\beta$-cell mass by maintaining glucose-stimulated insulin secretion [126].

In addition to producing growth factors, M2-like macrophages release IL-10, which has direct effects on maintaining functional $\beta$-cell mass. $\beta$-cells exposed to IL-10 express elevated levels of anti-apoptotic genes [127]. IL-10 can induce $\beta$-cell iNOS protein levels, thus potentially decreasing NO levels [128]. Finally, IL-10 can enhance insulin secretion, as measured by c-peptide levels [129]. A recent publication showed that human islets have macrophages in the perivascular region that are the primary source of islet IL-10 levels, and that loss of the ability to produce IL-10 in the obese and diabetic state leads to $\beta$-cell loss [130].

Finally, islet expansion is dependent on the remodeling of the islet vasculature and the extracellular matrix (ECM), as well as the release of growth factors bound in the ECM. M2-like macrophages produce and secrete matrix metalloproteinases (MMP) that are critical for this process. Macrophages from human islets are the primary source of MMP9 [130]. Macrophages that migrate to the islets in a chronic pancreatitis model of diabetes express various M2-like markers, including MMP9, which is essential for islet vascularization and $\beta$-cell expansion [113]. Together, these data demonstrate the various factors secreted from the M2-like macrophages that have direct effects on maintaining functional $\beta$-cell mass.

Table 2. Macrophages secreted factors that have a positive effect on functional $\beta$-cell mass.

\begin{tabular}{|c|c|}
\hline Effectors & Target \\
\hline WNT3A & Increases $\beta$-cell proliferation and survival via $W n t / \beta$-catenin pathway $[107,117,118]$ \\
\hline RETINOIC ACID & Increased expression of RAR $\beta$ and increased insulin production and secretion [119] \\
\hline TGF $\beta 1$ & $\begin{array}{l}\text { Induces upregulation of SMAD7, which is responsible for increased } \beta \text {-cell proliferation [111] } \\
\text { Induces upregulation of SMAD2, which is a SMAD7 inhibitor [111] }\end{array}$ \\
\hline EGF & $\begin{array}{c}\text { Inhibits SMAD2 nuclear localization, working in conjunction with TGF } \beta 1 \text { to induce } \beta \text {-cell } \\
\text { proliferation [111] }\end{array}$ \\
\hline PDGF & Induces $\beta$-cell proliferation [122] \\
\hline IGF-1 & Promotes $\beta$-cell survival by maintaining GSIS [126] \\
\hline IL-10 & $\begin{array}{c}\text { Induces upregulation of anti-apoptotic genes, promoting greater } \beta \text {-cell survival [127] } \\
\text { Increases iNOS levels, decreasing NO levels in } \beta \text {-cells [128] } \\
\text { Increases insulin secretion [129] }\end{array}$ \\
\hline MMP9 & Promotes islet vascularization and $\beta$-cell expansion [113] \\
\hline
\end{tabular}

\section{Use of Macrophages to Improve Functional $\beta$-Cell Mass as a Treatment for Diabetes}

The previous studies demonstrate the potential for M2-like macrophages to be harnessed to ameliorate functional $\beta$-cell mass as a treatment for T1D and T2D. Various studies have begun to demonstrate this feasibility. While macrophages from long-term T1D patients have impaired ability to undergo M2-like activation [30], NOD mice treated with the BET antagonist I-BET151 demonstrated significant M2-like activation and $\beta$-cell regeneration [131]. Similarly, NOD mice that received adoptive transfer of M2-like macrophages resulted in greater than $80 \%$ protection against T1D phenotypes for over 3 months compared to NOD mice that did not receive adoptive macrophage transfer or mice that received adoptive transfer of non-M2-like macrophages [132]. In this model, it was shown that the adoptively transferred M2-like macrophages preferentially migrated to the pancreas, where a greater number of islets were maintained after M2-like macrophage adoptive transfer. Using an STZ model of $\beta$-cell injury, it was shown that adoptive transfer of M2-like macrophages was sufficient to protect functional $\beta$-cell mass and diabetes-induced kidney damage. Mice that received M2-like macrophage adoptive transfer had greater islet area, as well as improved $\mathrm{HbA} 1 \mathrm{c}$ and non-fasting blood glucose levels [133]. Finally, STZ mice transplanted with mesenchymal stem cells resulted in improved fasting blood glucose, $\beta$-cell area, and $\beta$-cell proliferation. This corresponded with increased infiltration of 
M2-like macrophages [117]. It was shown that the mesenchymal stem cells were inducing endogenous macrophages to undergo M2-like activation. The M2-like macrophages induced $\beta$-cell proliferation through induction of the Wnt3a/ $\beta$-catenin signaling pathway. Although these preliminary rodent studies demonstrate the ability of M2-like macrophages to block or reverse diabetes progression and loss of functional $\beta$-cell mass, future studies in humans will be required.

\section{Concluding Remarks}

The purpose of this review was to highlight the detrimental and beneficial effects of macrophages, based on their activation state, on functional $\beta$-cell mass. From the studies reviewed here, it is clear that macrophages can have opposing effects on the $\beta$-cell. The various signals from the islet, from other autoimmune cells, and from systemic inflammation present in either T1D or T2D have the potential to induce M1-like activation of the macrophage and macrophage-mediated decrease in functional $\beta$-cell mass. Alternatively, signals from the $\beta$-cell under normal physiology or in response to certain forms of $\beta$-cell damage can result in M2-like macrophage activation and secretion of factors that promote $\beta$-cell proliferation, survival, and insulin secretion.

One potential caveat of these findings is the applicability to human $\beta$-cells. Given the physiological differences between rodent and human islets, it will be essential to validate the beneficial effects of M2-like macrophages that have been observed in rodent islets in human islets. Rodent islets or mice were the primary models used in the majority of studies cited in this review (Table 3). Fortunately, there are more and more studies looking at the effect of macrophages on human islets, or exploring the role of macrophages in vivo on human functional $\beta$-cell mass. For the greater application of these findings, these studies will need to be expanded.

Table 3. References that studied the effect of M1-like or M2-like macrophages on rodent islets, human islets, or both.

\begin{tabular}{cr}
\hline Rodent or Human Islets & References \\
\hline Rodent & {$[18,25,26,31-34,37,38,40,42,45-47,50-52,55,56,58,62,64,67,71,73,79,86,89,94,98,99$,} \\
& $102,103,106-108,111,113,115,116,118,119,121,123,124,127,132,133]$ \\
\hline Human & {$[27,28,30,36,39,43,48,61,63,69,77,78,100,104,117,130,131]$} \\
\hline Both & {$[5,17,20,59,66,76,93,97,120]$} \\
\hline
\end{tabular}

A clearer understanding of the processes of macrophage activation and the macrophage produced factors that directly affect the $\beta$-cell could be utilized as a potential therapeutic to maintain and expand functional $\beta$-cell mass as a treatment for both T1D and T2D (Figure 2). Furthermore, understanding the differences between resident and recruited macrophages and their ability to maintain or damage $\beta$-cells may be leveraged to improve patient care. In addition to having direct application to T1D, these findings may be applicable to other autoimmune disorders. Similarly, understanding the macrophage-mediated changes observed at the pancreatic islet in T2D may be beneficial for other obesity-related pathologies in other organs. 


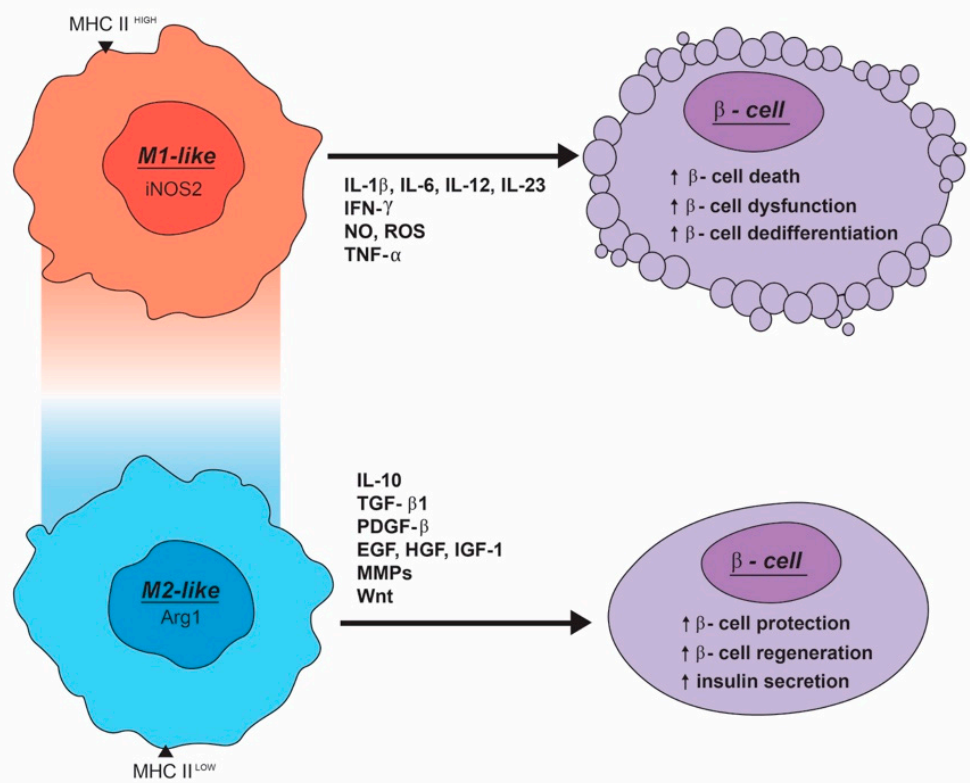

Figure 2. How the M1-like and M2-like extremes of the macrophage activation spectrum affect $\beta$-cell function, survival, and proliferation through secreted factors. M1-like macrophages are inflammatory in nature, producing and secreting inflammatory cytokines, NO, and ROS. M2-like macrophages play more of a protective role by inducing $\beta$-cell survival and proliferation. M2-like macrophages secrete anti-inflammatory cytokines, signaling peptides, and enzymes involved in tissue remodeling, inducing $\beta$-cell proliferation and enhancing insulin secretion.

Author Contributions: D.M.J., K.V.H., A.T.M., and J.S.T. each contributed to the investigation and writing of this manuscript. All authors have read and agreed to the published version of the manuscript.

Funding: This research was funded by The Beatson Foundation, grant number 2019-003 (J.S.T.).

Acknowledgments: The authors thank the members of the Tessem lab at BYU for critical discussion regarding these topics.

Conflicts of Interest: The authors declare no conflict of interest.

$\begin{array}{ll}\text { Abbreviations } \\ \text { Aldh1a2 } & \text { Aldehyde dehydrogenase } 1 \text { family, member A2 } \\ \text { ARG1 } & \text { Arginase 1 } \\ \text { ATF3 } & \text { Activating transcription factor } 3 \\ \text { ATF4 } & \text { Activating transcription factor } 4 \\ \text { ATP } & \text { Adenosine triphosphate } \\ \text { BET } & \text { Bromodomain and extraterminal domain family } \\ \text { BIP } & \text { Binding immunoglobulin protein } \\ \text { CCL17 } & \text { Chemokine (C-C motif) ligand 17 } \\ \text { CCL20 } & \text { Chemokine (C-C motif) ligand 20 } \\ \text { CCL24 } & \text { Chemokine (C-C motif) ligand 24 } \\ \text { CCL5 } & \text { Chemokine (C-C motif) ligand } 5 \\ \text { CHI3L1 } & \text { Chitinase 3 Like 1 } \\ \text { CHOP } & \text { CCAAT/enhancer binding protein (C/EBP) homologous protein } \\ \text { CSF-1 } & \text { Macrophage colony-stimulating factor } \\ \text { CSF-1R } & \text { Colony-stimulating 1 receptor } \\ \text { CSF-2 } & \text { Granulocyte-macrophage colony-stimulating factor } \\ \text { CXCL1 } & \text { Chemokine (C-X-C motif) ligand 1 } \\ \text { CXCL10 } & \text { Chemokine (C-X-C motif) ligand 10 (see also IP-10) } \\ \text { CXCL2 } & \text { Chemokine (C-X-C motif) ligand 2 } \\ \text { CXCL8 } & \text { Chemokine (C-X-C motif) ligand } 8\end{array}$


CXCL9 Chemokine (C-X-C motif) ligand 9

CXCR2 Chemokine (C-X-C motif) receptor 2

$\mathrm{Db} / \mathrm{db} \quad$ Diabetic mouse model

DNA Deoxyribonucleic acid

DP-BB BioBreeding Diabetes Prone rat

ECM Extracellular matrix

EGF Endothelial growth factor

ER Endoplasmic reticulum

ERK Extracellular signal-regulated kinase

Fas Apoptosis antigen 1

Foxo1 Forkhead box protein O1

GCSF Granulocyte colony-stimulating factor

GK Goto-Kakizaki rat

GSIS Glucose-stimulated insulin secretion

HGF Hepatocyte growth factor

I-BET151 BET bromodomain inhibitor

IFN- $\gamma \quad$ Interferon-gamma

IFNGR Interferon gamma receptor

IGF Insulin-like growth factor

IGF-1 Insulin-like growth factor 1

IL-1 Interleukin-1

IL-12 Interleukin-12

IL-13 Interleukin-13

IL-18 Interleukin-18

IL-1 $\beta \quad$ Interleukin-1 beta

IL-21 Interleukin-21

IL-33 Interleukin-33

IL-4 Interleukin-4

IL-6 Interleukin-6

IL-8 Interleukin-8

iNOS Inducible nitric oxide synthase

iNOS2 Inducible nitric oxide synthase 2

IP-10 Chemokine (C-X-C motif) ligand 10 (see also CXCL10)

IRF-1 Interferon regulatory factor 1

Isl-1 Insulin gene enhancer protein 1

JAK/STAT Janus kinase/signal transducer and activator of transcription

JNK c-Jun N-terminal kinase

Kcnj11 Potassium Inwardly Rectifying Channel Subfamily J Member 11

LPS Lipopolysaccharide

$\mathrm{mAb} \quad$ Monoclonal antibody

MafA MAF BZIP Transcription Factor A

MAPK Mitogen-activated protein kinase

MCP-1 Monocyte chemoattractant protein-1

M-CSF Macrophage colony-stimulating factor

MerTK Tyrosine-protein kinase MER

Min6 Mouse insulinoma cell line

MIP1 $\alpha$ Macrophage inflammatory protein-1 alpha

MMP Metalloproteinase

MMP9 Metalloproteinase 9

mRNA Messenger ribonucleic acid

NAD Nicotinamide adenine dinucleotide

NADPH Nicotinamide adenine dinucleotide phosphate

NF- $\kappa B \quad$ Nuclear factor kappa-light-chain-enhancer of activated B cells

NLRP3 NOD-, LRR- and pyrin domain containing 3

NO Nitric oxide

NOD Non-obese diabetic 


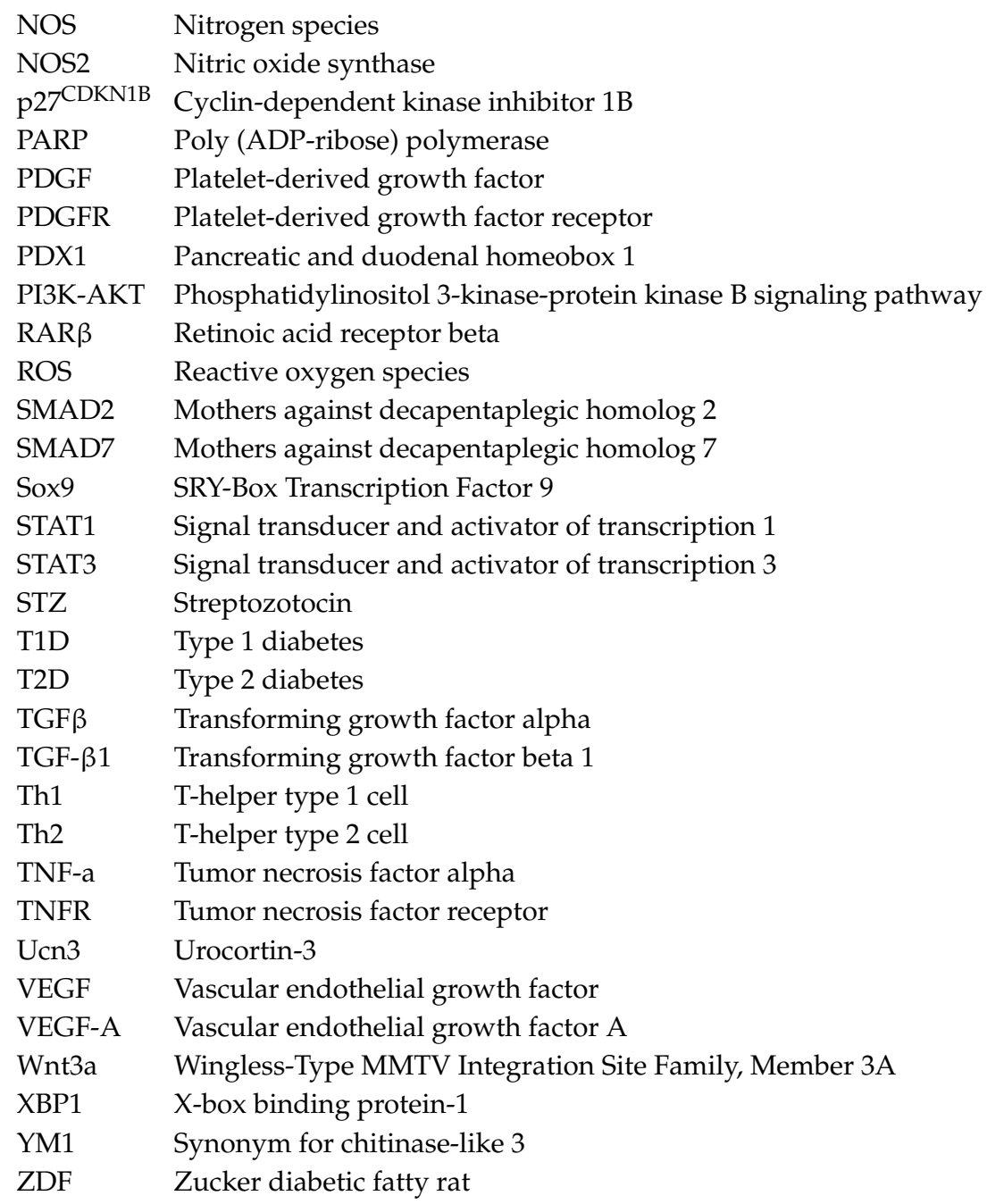

Note: References $[5,30,33,37-39,43,47,58,69,76,102-104,107,113,115-117,122,130-133]$ indicates key finding in the field, relative to this topic.

\section{References}

1. Saeedi, P.; Petersohn, I.; Salpea, P.; Malanda, B.; Karuranga, S.; Unwin, N.; Colagiuri, S.; Guariguata, L.; Motala, A.A.; Ogurtsova, K.; et al. Global and regional diabetes prevalence estimates for 2019 and projections for 2030 and 2045: Results from the International Diabetes Federation Diabetes Atlas, 9th edition. Diabetes Res. Clin. Pr. 2019, 157. [CrossRef] [PubMed]

2. Mallone, R.; Eizirik, D.L. Presumption of innocence for beta cells: Why are they vulnerable autoimmune targets in type 1 diabetes? Diabetologia 2020, 63, 1999-2006. [CrossRef] [PubMed]

3. Efrat, S. Beta-Cell Dedifferentiation in Type 2 Diabetes: Concise Review. Stem Cells 2019, 37, $1267-1272$. [CrossRef] [PubMed]

4. Pugliese, A. Insulitis in the pathogenesis of type 1 diabetes. Pediatr. Diabetes 2016, 17, 31-36. [CrossRef]

5. Ying, W.; Fu, W.X.; Lee, Y.S.; Olefsky, J.M. The role of macrophages in obesity-associated islet inflammation and beta-cell abnormalities. Nat. Rev. Endocrinol. 2020, 16, 81-90. [CrossRef]

6. Saunders, D.; Powers, A.C. Replicative capacity of beta-cells and type 1 diabetes. J. Autoimmun. 2016, 71, 59-68. [CrossRef]

7. Ley, K. M1 Means Kill; M2 Means Heal. J. Immunol. 2017, 199, 2191-2193. [CrossRef]

8. Poltavets, A.S.; Vishnyakova, P.A.; Elchaninov, A.V.; Sukhikh, G.T.; Fatkhudinov, T.K. Macrophage Modification Strategies for Efficient Cell Therapy. Cells 2020, 9, 1535. [CrossRef]

9. Eguchi, K.; Nagai, R. Islet inflammation in type 2 diabetes and physiology. J. Clin. Investig. 2017, 127, 14-23. [CrossRef] 
10. Van Gassen, N.; Staels, W.; Van Overmeire, E.; De Groef, S.; Sojoodi, M.; Heremans, Y.; Leuckx, G.; Van de Casteele, M.; Van Ginderachter, J.A.; Heimberg, H.; et al. Concise Review: Macrophages: Versatile Gatekeepers During Pancreatic beta-Cell Development, Injury, and Regeneration. Stem Cells Transl. Med. 2015, 4, 555-563. [CrossRef]

11. Schulz, C.; Gomez Perdiguero, E.; Chorro, L.; Szabo-Rogers, H.; Cagnard, N.; Kierdorf, K.; Prinz, M.; Wu, B.; Jacobsen, S.E.; Pollard, J.W.; et al. A lineage of myeloid cells independent of Myb and hematopoietic stem cells. Science 2012, 336, 86-90. [CrossRef] [PubMed]

12. Ginhoux, F.; Guilliams, M. Tissue-Resident Macrophage Ontogeny and Homeostasis. Immunity 2016, 44, 439-449. [CrossRef] [PubMed]

13. Jezek, P.; Jaburek, M.; Holendova, B.; Plecita-Hlavata, L. Fatty Acid-Stimulated Insulin Secretion vs. Lipotoxicity. Molecules 2018, 23, 1483. [CrossRef] [PubMed]

14. Hume, D.A. The Many Alternative Faces of Macrophage Activation. Front. Immunol. 2015, 6, 370. [CrossRef] [PubMed]

15. Orecchioni, M.; Ghosheh, Y.; Pramod, A.B.; Ley, K. Macrophage Polarization: Different Gene Signatures in M1(LPS+) vs. Classically and M2(LPS-) vs. Alternatively Activated Macrophages. Front. Immunol. 2019, 10, 1084. [CrossRef] [PubMed]

16. Mantovani, A.; Biswas, S.K.; Galdiero, M.R.; Sica, A.; Locati, M. Macrophage plasticity and polarization in tissue repair and remodelling. J. Pathol. 2013, 229, 176-185. [CrossRef] [PubMed]

17. Donath, M.Y.; Dalmas, E.; Sauter, N.S.; Boni-Schnetzler, M. Inflammation in obesity and diabetes: Islet dysfunction and therapeutic opportunity. Cell Metab. 2013, 17, 860-872. [CrossRef]

18. Jourdan, T.; Godlewski, G.; Cinar, R.; Bertola, A.; Szanda, G.; Liu, J.; Tam, J.; Han, T.; Mukhopadhyay, B.; Skarulis, M.C.; et al. Activation of the Nlrp3 inflammasome in infiltrating macrophages by endocannabinoids mediates beta cell loss in type 2 diabetes. Nat. Med. 2013, 19, 1132-1140. [CrossRef]

19. Liu, G.; Yang, H. Modulation of macrophage activation and programming in immunity. J. Cell Physiol. 2013, 228, 502-512. [CrossRef]

20. Aamodt, K.I.; Powers, A.C. Signals in the pancreatic islet microenvironment influence beta-cell proliferation. Diabetes Obes. Metab. 2017, 19, 124-136. [CrossRef]

21. Zizzo, G.; Hilliard, B.A.; Monestier, M.; Cohen, P.L. Efficient clearance of early apoptotic cells by human macrophages requires M2c polarization and MerTK induction. J. Immunol. 2012, 189, 3508-3520. [CrossRef] [PubMed]

22. Mosser, D.M.; Edwards, J.P. Exploring the full spectrum of macrophage activation. Nat. Rev. Immunol. 2008, 8, 958-969. [CrossRef] [PubMed]

23. Ferrante, C.J.; Leibovich, S.J. Regulation of Macrophage Polarization and Wound Healing. Adv. Wound Care 2012, 1, 10-16. [CrossRef] [PubMed]

24. Grinberg, S.; Hasko, G.; Wu, D.; Leibovich, S.J. Suppression of PLCbeta2 by endotoxin plays a role in the adenosine $\mathrm{A}(2 \mathrm{~A})$ receptor-mediated switch of macrophages from an inflammatory to an angiogenic phenotype. Am. J. Pathol. 2009, 175, 2439-2453. [CrossRef] [PubMed]

25. Burg, A.R.; Tse, H.M. Redox-Sensitive Innate Immune Pathways During Macrophage Activation in Type 1 Diabetes. Antioxid. Redox Signal. 2018, 29, 1373-1398. [CrossRef] [PubMed]

26. Oschilewski, U.; Kiesel, U.; Kolb, H. Administration of silica prevents diabetes in BB-rats. Diabetes 1985, 34, 197-199. [CrossRef]

27. Hanninen, A.; Jalkanen, S.; Salmi, M.; Toikkanen, S.; Nikolakaros, G.; Simell, O. Macrophages, T cell receptor usage, and endothelial cell activation in the pancreas at the onset of insulin-dependent diabetes mellitus. J. Clin. Investig. 1992, 90, 1901-1910. [CrossRef]

28. Gaglia, J.L.; Guimaraes, A.R.; Harisinghani, M.; Turvey, S.E.; Jackson, R.; Benoist, C.; Mathis, D.; Weissleder, R. Noninvasive imaging of pancreatic islet inflammation in type 1A diabetes patients. J. Clin. Investig. 2011, 121, 442-445. [CrossRef]

29. Nunemaker, C.S. Considerations for Defining Cytokine Dose, Duration, and Milieu That Are Appropriate for Modeling Chronic Low-Grade Inflammation in Type 2 Diabetes. J. Diabetes Res. 2016, 2016, 2846570. [CrossRef]

30. Juhas, U.; Ryba-Stanislawowska, M.; Brandt-Varma, A.; Mysliwiec, M.; Mysliwska, J. Monocytes of newly diagnosed juvenile DM1 patients are prone to differentiate into regulatory IL-10(+) M2 macrophages. Immunol. Res. 2019, 67, 58-69. [CrossRef] 
31. El Hadri, K.; Mahmood, D.F.; Couchie, D.; Jguirim-Souissi, I.; Genze, F.; Diderot, V.; Syrovets, T.; Lunov, O.; Simmet, T.; Rouis, M. Thioredoxin-1 promotes anti-inflammatory macrophages of the M2 phenotype and antagonizes atherosclerosis. Arterioscler. Thromb. Vasc. Biol. 2012, 32, 1445-1452. [CrossRef] [PubMed]

32. Padgett, L.E.; Burg, A.R.; Lei, W.; Tse, H.M. Loss of NADPH oxidase-derived superoxide skews macrophage phenotypes to delay type 1 diabetes. Diabetes 2015, 64, 937-946. [CrossRef] [PubMed]

33. Ehses, J.A.; Perren, A.; Eppler, E.; Ribaux, P.; Pospisilik, J.A.; Maor-Cahn, R.; Gueripel, X.; Ellingsgaard, H.; Schneider, M.K.; Biollaz, G.; et al. Increased number of islet-associated macrophages in type 2 diabetes. Diabetes 2007, 56, 2356-2370. [CrossRef]

34. Masters, S.L.; Dunne, A.; Subramanian, S.L.; Hull, R.L.; Tannahill, G.M.; Sharp, F.A.; Becker, C.; Franchi, L.; Yoshihara, E.; Chen, Z.; et al. Activation of the NLRP3 inflammasome by islet amyloid polypeptide provides a mechanism for enhanced IL-1beta in type 2 diabetes. Nat. Immunol. 2010, 11, 897-904. [CrossRef]

35. Masters, S.L.; Mielke, L.A.; Cornish, A.L.; Sutton, C.E.; O’Donnell, J.; Cengia, L.H.; Roberts, A.W.; Wicks, I.P.; Mills, K.H.; Croker, B.A. Regulation of interleukin-1beta by interferon-gamma is species specific, limited by suppressor of cytokine signalling 1 and influences interleukin-17 production. EMBO Rep. 2010, 11, 640-646. [CrossRef]

36. Eguchi, K.; Manabe, I.; Oishi-Tanaka, Y.; Ohsugi, M.; Kono, N.; Ogata, F.; Yagi, N.; Ohto, U.; Kimoto, M.; Miyake, K.; et al. Saturated fatty acid and TLR signaling link beta cell dysfunction and islet inflammation. Cell Metab. 2012, 15, 518-533. [CrossRef]

37. Westwell-Roper, C.Y.; Ehses, J.A.; Verchere, C.B. Resident macrophages mediate islet amyloid polypeptide-induced islet IL-1beta production and beta-cell dysfunction. Diabetes 2014, 63, 1698-1711. [CrossRef]

38. Richardson, S.J.; Willcox, A.; Bone, A.J.; Foulis, A.K.; Morgan, N.G. Islet-associated macrophages in type 2 diabetes. Diabetologia 2009, 52, 1686-1688. [CrossRef]

39. Kamata, K.; Mizukami, H.; Inaba, W.; Tsuboi, K.; Tateishi, Y.; Yoshida, T.; Yagihashi, S. Islet amyloid with macrophage migration correlates with augmented beta-cell deficits in type 2 diabetic patients. Amyloid 2014, 21, 191-201. [CrossRef]

40. Collier, J.J.; Sparer, T.E.; Karlstad, M.D.; Burke, S.J. Pancreatic islet inflammation: An emerging role for chemokines. J. Mol. Endocrinol. 2017, 59, R33-R46. [CrossRef]

41. Talchai, C.; Xuan, S.; Lin, H.V.; Sussel, L.; Accili, D. Pancreatic beta cell dedifferentiation as a mechanism of diabetic beta cell failure. Cell 2012, 150, 1223-1234. [CrossRef] [PubMed]

42. Chan, J.Y.; Lee, K.; Maxwell, E.L.; Liang, C.; Laybutt, D.R. Macrophage alterations in islets of obese mice linked to beta cell disruption in diabetes. Diabetologia 2019, 62, 993-999. [CrossRef] [PubMed]

43. He, W.; Yuan, T.; Maedler, K. Macrophage-associated pro-inflammatory state in human islets from obese individuals. Nutr. Diabetes 2019, 9, 36. [CrossRef] [PubMed]

44. Delmastro, M.M.; Piganelli, J.D. Oxidative stress and redox modulation potential in type 1 diabetes. Clin. Dev. Immunol. 2011, 2011, 593863. [CrossRef] [PubMed]

45. Burke, S.J.; Batdorf, H.M.; Burk, D.H.; Martin, T.M.; Mendoza, T.; Stadler, K.; Alami, W.; Karlstad, M.D.; Robson, M.J.; Blakely, R.D.; et al. Pancreatic deletion of the interleukin-1 receptor disrupts whole body glucose homeostasis and promotes islet beta-cell de-differentiation. Mol. Metab. 2018, 14, 95-107. [CrossRef] [PubMed]

46. Burke, S.J.; Stadler, K.; Lu, D.; Gleason, E.; Han, A.; Donohoe, D.R.; Rogers, R.C.; Hermann, G.E.; Karlstad, M.D.; Collier, J.J. IL-1beta reciprocally regulates chemokine and insulin secretion in pancreatic beta-cells via NF-kappaB. Am. J. Physiol. Endocrinol. Metab. 2015, 309, E715-E726. [CrossRef]

47. Dror, E.; Dalmas, E.; Meier, D.T.; Wueest, S.; Thevenet, J.; Thienel, C.; Timper, K.; Nordmann, T.M.; Traub, S.; Schulze, F.; et al. Postprandial macrophage-derived IL-1beta stimulates insulin, and both synergistically promote glucose disposal and inflammation. Nat. Immunol. 2017, 18, 283-292. [CrossRef]

48. Welsh, N.; Cnop, M.; Kharroubi, I.; Bugliani, M.; Lupi, R.; Marchetti, P.; Eizirik, D.L. Is there a role for locally produced interleukin-1 in the deleterious effects of high glucose or the type 2 diabetes milieu to human pancreatic islets? Diabetes 2005, 54, 3238-3244. [CrossRef]

49. Eizirik, D.L.; Mandrup-Poulsen, T. A choice of death-The signal-transduction of immune-mediated beta-cell apoptosis. Diabetologia 2001, 44, 2115-2133. [CrossRef] 
50. Ablamunits, V.; Henegariu, O.; Hansen, J.B.; Opare-Addo, L.; Preston-Hurlburt, P.; Santamaria, P.; Mandrup-Poulsen, T.; Herold, K.C. Synergistic reversal of type 1 diabetes in NOD mice with anti-CD3 and interleukin-1 blockade: Evidence of improved immune regulation. Diabetes 2012, 61, 145-154. [CrossRef]

51. O'Neill, C.M.; Lu, C.; Corbin, K.L.; Sharma, P.R.; Dula, S.B.; Carter, J.D.; Ramadan, J.W.; Xin, W.; Lee, J.K.; Nunemaker, C.S. Circulating levels of IL-1B+IL-6 cause ER stress and dysfunction in islets from prediabetic male mice. Endocrinology 2013, 154, 3077-3088. [CrossRef] [PubMed]

52. Burkart, V.; Wang, Z.Q.; Radons, J.; Heller, B.; Herceg, Z.; Stingl, L.; Wagner, E.F.; Kolb, H. Mice lacking the poly(ADP-ribose) polymerase gene are resistant to pancreatic beta-cell destruction and diabetes development induced by streptozocin. Nat. Med. 1999, 5, 314-319. [CrossRef]

53. Westwell-Roper, C.; Dai, D.L.; Soukhatcheva, G.; Potter, K.J.; van Rooijen, N.; Ehses, J.A.; Verchere, C.B. IL-1 blockade attenuates islet amyloid polypeptide-induced proinflammatory cytokine release and pancreatic islet graft dysfunction. J. Immunol. 2011, 187, 2755-2765. [CrossRef] [PubMed]

54. Bouzakri, K.; Ribaux, P.; Tomas, A.; Parnaud, G.; Rickenbach, K.; Halban, P.A. Rab GTPase-activating protein AS160 is a major downstream effector of protein kinase B/Akt signaling in pancreatic beta-cells. Diabetes 2008, 57, 1195-1204. [CrossRef] [PubMed]

55. Zawalich, W.S.; Zawalich, K.C. Interleukin 1 is a potent stimulator of islet insulin secretion and phosphoinositide hydrolysis. Am. J. Physiol. 1989, 256, E19-E24. [CrossRef] [PubMed]

56. Cucak, H.; Mayer, C.; Tonnesen, M.; Thomsen, L.H.; Grunnet, L.G.; Rosendahl, A. Macrophage Contact Dependent and Independent TLR4 Mechanisms Induce beta-Cell Dysfunction and Apoptosis in a Mouse Model of Type 2 Diabetes. PLOS ONE 2014, 9. [CrossRef]

57. Zhou, R.; Tardivel, A.; Thorens, B.; Choi, I.; Tschopp, J. Thioredoxin-interacting protein links oxidative stress to inflammasome activation. Nat. Immunol. 2010, 11, 136-140. [CrossRef]

58. Ehses, J.A.; Lacraz, G.; Giroix, M.H.; Schmidlin, F.; Coulaud, J.; Kassis, N.; Irminger, J.C.; Kergoat, M.; Portha, B.; Homo-Delarche, F.; et al. IL-1 antagonism reduces hyperglycemia and tissue inflammation in the type 2 diabetic GK rat. Proc. Natl. Acad. Sci. USA 2009, 106, 13998-14003. [CrossRef]

59. Sauter, N.S.; Thienel, C.; Plutino, Y.; Kampe, K.; Dror, E.; Traub, S.; Timper, K.; Bedat, B.; Pattou, F.; Kerr-Conte, J.; et al. Angiotensin II induces interleukin-1beta-mediated islet inflammation and beta-cell dysfunction independently of vasoconstrictive effects. Diabetes 2015, 64, 1273-1283. [CrossRef]

60. Novak, I.; Solini, A. P2X receptor-ion channels in the inflammatory response in adipose tissue and pancreas-potential triggers in onset of type 2 diabetes? Curr. Opin. Immunol. 2018, 52, 1-7. [CrossRef]

61. Cnop, M.; Abdulkarim, B.; Bottu, G.; Cunha, D.A.; Igoillo-Esteve, M.; Masini, M.; Turatsinze, J.V.; Griebel, T.; Villate, O.; Santin, I.; et al. RNA sequencing identifies dysregulation of the human pancreatic islet transcriptome by the saturated fatty acid palmitate. Diabetes 2014, 63, 1978-1993. [CrossRef] [PubMed]

62. Diana, J.; Lehuen, A. Macrophages and beta-cells are responsible for CXCR2-mediated neutrophil infiltration of the pancreas during autoimmune diabetes. EMBO Mol. Med. 2014, 6, 1090-1104. [CrossRef]

63. Eizirik, D.L.; Sammeth, M.; Bouckenooghe, T.; Bottu, G.; Sisino, G.; Igoillo-Esteve, M.; Ortis, F.; Santin, I.; Colli, M.L.; Barthson, J.; et al. The human pancreatic islet transcriptome: Expression of candidate genes for type 1 diabetes and the impact of pro-inflammatory cytokines. PLoS Genet. 2012, 8, e1002552. [CrossRef]

64. Ward, M.G.; Li, G.; Hao, M. Apoptotic beta-cells induce macrophage reprogramming under diabetic conditions. J. Biol. Chem. 2018, 293, 16160-16173. [CrossRef]

65. Riera-Borrull, M.; Cuevas, V.D.; Alonso, B.; Vega, M.A.; Joven, J.; Izquierdo, E.; Corbi, A.L. Palmitate Conditions Macrophages for Enhanced Responses toward Inflammatory Stimuli via JNK Activation. J. Immunol. 2017, 199, 3858-3869. [CrossRef]

66. Hajmrle, C.; Smith, N.; Spigelman, A.F.; Dai, X.; Senior, L.; Bautista, A.; Ferdaoussi, M.; MacDonald, P.E. Interleukin-1 signaling contributes to acute islet compensation. JCI Insight 2016, 1, e86055. [CrossRef]

67. Zawalich, W.S.; Dierolf, B.; Zawalich, K.C. Interleukin-1 induces time-dependent potentiation in isolated rat islets: Possible involvement of phosphoinositide hydrolysis. Endocrinology 1989, 124, 720-726. [CrossRef]

68. Dasu, M.R.; Devaraj, S.; Jialal, I. High glucose induces IL-1beta expression in human monocytes: Mechanistic insights. Am. J. Physiol. Endocrinol. Metab. 2007, 293, E337-E346. [CrossRef]

69. Nordmann, T.M.; Dror, E.; Schulze, F.; Traub, S.; Berishvili, E.; Barbieux, C.; Boni-Schnetzler, M.; Donath, M.Y. The Role of Inflammation in beta-cell Dedifferentiation. Sci. Rep. 2017, 7, 6285. [CrossRef] 
70. Oshima, M.; Knoch, K.P.; Diedisheim, M.; Petzold, A.; Cattan, P.; Bugliani, M.; Marchetti, P.; Choudhary, P.; Huang, G.C.; Bornstein, S.R.; et al. Virus-like infection induces human beta cell dedifferentiation. JCI Insight 2018, 3. [CrossRef]

71. Ibarra Urizar, A.; Prause, M.; Wortham, M.; Sui, Y.; Thams, P.; Sander, M.; Christensen, G.L.; Billestrup, N. Beta-cell dysfunction induced by non-cytotoxic concentrations of Interleukin-1beta is associated with changes in expression of beta-cell maturity genes and associated histone modifications. Mol. Cell. Endocrinol. 2019, 496, 110524. [CrossRef] [PubMed]

72. Kaneto, H.; Xu, G.; Fujii, N.; Kim, S.; Bonner-Weir, S.; Weir, G.C. Involvement of c-Jun N-terminal kinase in oxidative stress-mediated suppression of insulin gene expression. J. Biol. Chem. 2002, 277, 30010-30018. [CrossRef] [PubMed]

73. Spinas, G.A.; Hansen, B.S.; Linde, S.; Kastern, W.; Molvig, J.; Mandruppoulsen, T.; Dinarello, C.A.; Nielsen, J.H.; Nerup, J. Interleukin-1 Dose-Dependently Affects the Biosynthesis of (Pro)Insulin in Isolated Rat Islets of Langerhans. Diabetologia 1987, 30, 474-480. [CrossRef] [PubMed]

74. Tanaka, T.; Narazaki, M.; Kishimoto, T. IL-6 in inflammation, immunity, and disease. Cold Spring Harb. Perspect. Biol. 2014, 6, a016295. [CrossRef]

75. Kristiansen, O.P.; Mandrup-Poulsen, T. Interleukin-6 and diabetes: The good, the bad, or the indifferent? Diabetes 2005, 54, S114-S124. [CrossRef]

76. Brozzi, F.; Nardelli, T.R.; Lopes, M.; Millard, I.; Barthson, J.; Igoillo-Esteve, M.; Grieco, F.A.; Villate, O.; Oliveira, J.M.; Casimir, M.; et al. Cytokines induce endoplasmic reticulum stress in human, rat and mouse beta cells via different mechanisms. Diabetologia 2015, 58, 2307-2316. [CrossRef]

77. Maedler, K.; Spinas, G.A.; Lehmann, R.; Sergeev, P.; Weber, M.; Fontana, A.; Kaiser, N.; Donath, M.Y. Glucose induces beta-cell apoptosis via upregulation of the Fas receptor in human islets. Diabetes 2001, 50, 1683-1690. [CrossRef]

78. He, W.; Rebello, O.; Savino, R.; Terracciano, R.; Schuster-Klein, C.; Guardiola, B.; Maedler, K. TLR4 triggered complex inflammation in human pancreatic islets. Biochim. Biophys. Acta Mol. Basis. Dis. 2019, 1865, 86-97. [CrossRef]

79. Nackiewicz, D.; Dan, M.; He, W.; Kim, R.; Salmi, A.; Rutti, S.; Westwell-Roper, C.; Cunningham, A.; Speck, M.; Schuster-Klein, C.; et al. TLR2/6 and TLR4-activated macrophages contribute to islet inflammation and impair beta cell insulin gene expression via IL-1 and IL-6. Diabetologia 2014, 57, 1645-1654. [CrossRef]

80. Baltrusch, S. Mitochondrial network regulation and its potential interference with inflammatory signals in pancreatic beta cells. Diabetologia 2016, 59, 683-687. [CrossRef]

81. Zheng, Q.Y.; Cao, Z.H.; Hu, X.B.; Li, G.Q.; Dong, S.F.; Xu, G.L.; Zhang, K.Q. LIGHT/IFN-gamma triggers beta cells apoptosis via NF-kappaB/Bcl2-dependent mitochondrial pathway. J. Cell Mol. Med. 2016, 20, 1861-1871. [CrossRef]

82. Cao, Z.H.; -Zheng, Q.Y.; Li, G.Q.; Hu, X.B.; Feng, S.L.; Xu, G.L.; Zhang, K.Q. STAT1-mediated down-regulation of Bcl-2 expression is involved in IFN-gamma/TNF-alpha-induced apoptosis in NIT-1 cells. PLoS ONE 2015, 10, e0120921. [CrossRef]

83. Gysemans, C.A.; Ladriere, L.; Callewaert, H.; Rasschaert, J.; Flamez, D.; Levy, D.E.; Matthys, P.; Eizirik, D.L.; Mathieu, C. Disruption of the gamma-interferon signaling pathway at the level of signal transducer and activator of transcription-1 prevents immune destruction of beta-cells. Diabetes 2005, 54, 2396-2403. [CrossRef]

84. Baldeon, M.E.; Chun, T.; Gaskins, H.R. Interferon-alpha and interferon-gamma differentially affect pancreatic beta-cell phenotype and function. Am. J. Physiol. 1998, 275, C25-C32. [CrossRef]

85. Freudenburg, W.; Gautam, M.; Chakraborty, P.; James, J.; Richards, J.; Salvatori, A.S.; Baldwin, A.; Schriewer, J.; Buller, R.M.L.; Corbett, J.A.; et al. Reduction in ATP Levels Triggers Immunoproteasome Activation by the $11 \mathrm{~S}$ (PA28) Regulator during Early Antiviral Response Mediated by IFN beta in Mouse Pancreatic beta-Cells. PLoS ONE 2013, 8, e52408. [CrossRef]

86. Heitmeier, M.R.; Scarim, A.L.; Corbett, J.A. Interferon-gamma increases the sensitivity of islets of Langerhans for inducible nitric-oxide synthase expression induced by interleukin 1. J. Biol. Chem. 1997, 272, 13697-13704. [CrossRef]

87. Oleson, B.J.; Corbett, J.A. Dual Role of Nitric Oxide in Regulating the Response of beta Cells to DNA Damage. Antioxid. Redox Sign. 2018, 29, 1432-1445. [CrossRef]

88. Hughes, K.J.; Meares, G.P.; Hansen, P.A.; Corbett, J.A. FoxO1 and SIRT1 Regulate beta-Cell Responses to Nitric Oxide. J. Biol. Chem. 2011, 286, 8338-8348. [CrossRef] 
89. Dahlen, E.; Dawe, K.; Ohlsson, L.; Hedlund, G. Dendritic cells and macrophages are the first and major producers of TNF-alpha in pancreatic islets in the nonobese diabetic mouse. J. Immunol. 1998, 160, 3585-3593.

90. Odegaard, J.I.; Chawla, A. Connecting Type 1 and Type 2 Diabetes through Innate Immunity. Cold Spring Harb. Perspect. Med. 2012, 2. [CrossRef]

91. Janjuha, S.; Singh, S.P.; Tsakmaki, A.; Mousavy Gharavy, S.N.; Murawala, P.; Konantz, J.; Birke, S.; Hodson, D.J.; Rutter, G.A.; Bewick, G.A.; et al. Age-related islet inflammation marks the proliferative decline of pancreatic beta-cells in zebrafish. eLife 2018, 7. [CrossRef] [PubMed]

92. Turner, D.A.; Paszek, P.; Woodcock, D.J.; Nelson, D.E.; Horton, C.A.; Wang, Y.; Spiller, D.G.; Rand, D.A.; White, M.R.; Harper, C.V. Physiological levels of TNFalpha stimulation induce stochastic dynamics of NF-kappaB responses in single living cells. J. Cell Sci. 2010, 123, 2834-2843. [CrossRef]

93. Eguchi, K.; Manabe, I. Macrophages and islet inflammation in type 2 diabetes. Diabetes Obes. Metab. 2013, 15 (Suppl. 3), 152-158. [CrossRef]

94. Morgan, D.; Oliveira-Emilio, H.R.; Keane, D.; Hirata, A.E.; Santos da Rocha, M.; Bordin, S.; Curi, R.; Newsholme, P.; Carpinelli, A.R. Glucose, palmitate and pro-inflammatory cytokines modulate production and activity of a phagocyte-like NADPH oxidase in rat pancreatic islets and a clonal beta cell line. Diabetologia 2007, 50, 359-369. [CrossRef] [PubMed]

95. Eizirik, D.L.; Flodstrom, M.; Karlsen, A.E.; Welsh, N. The harmony of the spheres: Inducible nitric oxide synthase and related genes in pancreatic beta cells. Diabetologia 1996, 39, 875-890. [CrossRef] [PubMed]

96. Quintana-Lopez, L.; Blandino-Rosano, M.; Perez-Arana, G.; Cebada-Aleu, A.; Lechuga-Sancho, A.; Aguilar-Diosdado, M.; Segundo, C. Nitric Oxide Is a Mediator of Antiproliferative Effects Induced by Proinflammatory Cytokines on Pancreatic Beta Cells. Mediat. Inflamm. 2013, 2013. [CrossRef] [PubMed]

97. Grunnet, L.G.; Aikin, R.; Tonnesen, M.F.; Paraskevas, S.; Blaabjerg, L.; Storling, J.; Rosenberg, L.; Billestrup, N.; Maysinger, D.; Mandrup-Poulsen, T. Proinflammatory cytokines activate the intrinsic apoptotic pathway in beta-cells. Diabetes 2009, 58, 1807-1815. [CrossRef]

98. Pavlovic, D.; Chen, M.C.; Gysemans, C.A.; Mathieu, C.; Eizirik, D.L. The role of interferon regulatory factor-1 in cytokine-induced mRNA expression and cell death in murine pancreatic beta-cells. Eur. Cytokine Netw. 1999, 10, 403-412.

99. Gysemans, C.; Callewaert, H.; Moore, F.; Nelson-Holte, M.; Overbergh, L.; Eizirik, D.L.; Mathieu, C. Interferon regulatory factor-1 is a key transcription factor in murine beta cells under immune attack. Diabetologia 2009, 52, 2374-2384. [CrossRef]

100. Grieco, F.A.; Moore, F.; Vigneron, F.; Santin, I.; Villate, O.; Marselli, L.; Rondas, D.; Korf, H.; Overbergh, L.; Dotta, F.; et al. IL-17A increases the expression of proinflammatory chemokines in human pancreatic islets. Diabetologia 2014, 57, 502-511. [CrossRef]

101. Parkash, J.; Chaudhry, M.A.; Rhoten, W.B. Tumor necrosis factor-alpha-induced changes in insulin-producing beta-cells. Anat. Rec. A Discov. Mol. Cell Evol. Biol. 2005, 286, 982-993. [CrossRef] [PubMed]

102. Geutskens, S.B.; Otonkoski, T.; Pulkkinen, M.A.; Drexhage, H.A.; Leenen, P.J. Macrophages in the murine pancreas and their involvement in fetal endocrine development in vitro. J. Leukoc. Biol. 2005, 78, 845-852. [CrossRef] [PubMed]

103. Banaei-Bouchareb, L.; Gouon-Evans, V.; Samara-Boustani, D.; Castellotti, M.C.; Czernichow, P.; Pollard, J.W.; Polak, M. Insulin cell mass is altered in Csf1op/Csf1op macrophage-deficient mice. J. Leukoc. Biol. 2004, 76, 359-367. [CrossRef] [PubMed]

104. Banaei-Bouchareb, L.; Peuchmaur, M.; Czernichow, P.; Polak, M. A transient microenvironment loaded mainly with macrophages in the early developing human pancreas. J. Endocrinol. 2006, 188, 467-480. [CrossRef] [PubMed]

105. Mosser, R.E.; Maulis, M.F.; Moulle, V.S.; Dunn, J.C.; Carboneau, B.A.; Arasi, K.; Pappan, K.; Poitout, V.; Gannon, M. High-fat diet-induced beta-cell proliferation occurs prior to insulin resistance in C57Bl/6J male mice. Am. J. Physiol. Endocrinol. Metab. 2015, 308, E573-E582. [CrossRef]

106. Woodland, D.C.; Liu, W.; Leong, J.; Sears, M.L.; Luo, P.; Chen, X. Short-term high-fat feeding induces islet macrophage infiltration and beta-cell replication independently of insulin resistance in mice. Am. J. Physiol. Endocrinol. Metab. 2016, 311, E763-E771. [CrossRef]

107. Criscimanna, A.; Coudriet, G.M.; Gittes, G.K.; Piganelli, J.D.; Esni, F. Activated macrophages create lineage-specific microenvironments for pancreatic acinar- and beta-cell regeneration in mice. Gastroenterology 2014, 147, 1106-1118.e1111. [CrossRef] 
108. Riley, K.G.; Pasek, R.C.; Maulis, M.F.; Dunn, J.C.; Bolus, W.R.; Kendall, P.L.; Hasty, A.H.; Gannon, M. Macrophages are essential for CTGF-mediated adult beta-cell proliferation after injury. Mol. Metab. 2015, 4, 584-591. [CrossRef]

109. Xiao, X.; Guo, P.; Prasadan, K.; Shiota, C.; Peirish, L.; Fischbach, S.; Song, Z.; Gaffar, I.; Wiersch, J.; El-Gohary, Y.; et al. Pancreatic cell tracing, lineage tagging and targeted genetic manipulations in multiple cell types using pancreatic ductal infusion of adeno-associated viral vectors and/or cell-tagging dyes. Nat. Protoc. 2014, 9, 2719-2724. [CrossRef]

110. Guo, P.; Preuett, B.; Krishna, P.; Xiao, X.; Shiota, C.; Wiersch, J.; Gaffar, I.; Tulachan, S.; El-Gohary, Y.; Song, Z.; et al. Barrier function of the coelomic epithelium in the developing pancreas. Mech. Dev. 2014, 134, 67-79. [CrossRef]

111. Xiao, X.; Gaffar, I.; Guo, P.; Wiersch, J.; Fischbach, S.; Peirish, L.; Song, Z.; El-Gohary, Y.; Prasadan, K.; Shiota, C.; et al. M2 macrophages promote beta-cell proliferation by up-regulation of SMAD7. Proc. Natl. Acad. Sci. USA 2014, 111, E1211-E1220. [CrossRef] [PubMed]

112. Xiao, X.; Prasadan, K.; Guo, P.; El-Gohary, Y.; Fischbach, S.; Wiersch, J.; Gaffar, I.; Shiota, C.; Gittes, G.K. Pancreatic duct cells as a source of VEGF in mice. Diabetologia 2014, 57, 991-1000. [CrossRef] [PubMed]

113. Tessem, J.S.; Jensen, J.N.; Pelli, H.; Dai, X.M.; Zong, X.H.; Stanley, E.R.; Jensen, J.; DeGregori, J. Critical roles for macrophages in islet angiogenesis and maintenance during pancreatic degeneration. Diabetes 2008, 57, 1605-1617. [CrossRef] [PubMed]

114. Reinert, R.B.; Cai, Q.; Hong, J.Y.; Plank, J.L.; Aamodt, K.; Prasad, N.; Aramandla, R.; Dai, C.; Levy, S.E.; Pozzi, A.; et al. Vascular endothelial growth factor coordinates islet innervation via vascular scaffolding. Development 2014, 141, 1480-1491. [CrossRef] [PubMed]

115. Brissova, M.; Aamodt, K.; Brahmachary, P.; Prasad, N.; Hong, J.Y.; Dai, C.; Mellati, M.; Shostak, A.; Poffenberger, G.; Aramandla, R.; et al. Islet microenvironment, modulated by vascular endothelial growth factor-A signaling, promotes beta cell regeneration. Cell Metab. 2014, 19, 498-511. [CrossRef]

116. Smeets, S.; Stange, G.; Leuckx, G.; Roelants, L.; Cools, W.; De Paep, D.L.; Ling, Z.; De Leu, N.; In't Veld, P. Evidence of Tissue Repair in Human Donor Pancreas After Prolonged Duration of Stay in Intensive Care. Diabetes 2020, 69, 401-412. [CrossRef]

117. Cao, X.; Han, Z.B.; Zhao, H.; Liu, Q. Transplantation of mesenchymal stem cells recruits trophic macrophages to induce pancreatic beta cell regeneration in diabetic mice. Int. J. Biochem. Cell Biol. 2014, 53, 372-379. [CrossRef]

118. Criscimanna, A.; Speicher, J.A.; Houshmand, G.; Shiota, C.; Prasadan, K.; Ji, B.; Logsdon, C.D.; Gittes, G.K.; Esni, F. Duct cells contribute to regeneration of endocrine and acinar cells following pancreatic damage in adult mice. Gastroenterology 2011, 141, 1451-1462.e6. [CrossRef]

119. Dalmas, E.; Lehmann, F.M.; Dror, E.; Wueest, S.; Thienel, C.; Borsigova, M.; Stawiski, M.; Traunecker, E.; Lucchini, F.C.; Dapito, D.H.; et al. Interleukin-33-Activated Islet-Resident Innate Lymphoid Cells Promote Insulin Secretion through Myeloid Cell Retinoic Acid Production. Immunity 2017, 47, 928-942.e927. [CrossRef]

120. El-Gohary, Y.; Tulachan, S.; Wiersch, J.; Guo, P.; Welsh, C.; Prasadan, K.; Paredes, J.; Shiota, C.; Xiao, X.; Wada, Y.; et al. A smad signaling network regulates islet cell proliferation. Diabetes 2014, 63, 224-236. [CrossRef]

121. El-Gohary, Y.; Tulachan, S.; Guo, P.; Welsh, C.; Wiersch, J.; Prasadan, K.; Paredes, J.; Shiota, C.; Xiao, X.; Wada, Y.; et al. Smad signaling pathways regulate pancreatic endocrine development. Dev. Biol. 2013, 378, 83-93. [CrossRef] [PubMed]

122. Ying, W.; Lee, Y.S.; Dong, Y.; Seidman, J.S.; Yang, M.; Isaac, R.; Seo, J.B.; Yang, B.H.; Wollam, J.; Riopel, M.; et al. Expansion of Islet-Resident Macrophages Leads to Inflammation Affecting beta Cell Proliferation and Function in Obesity. Cell Metab. 2019, 29, 457-474.e5. [CrossRef] [PubMed]

123. Nishikoba, N.; Kumagai, K.; Kanmura, S.; Nakamura, Y.; Ono, M.; Eguchi, H.; Kamibayashiyama, T.; Oda, K.; Mawatari, S.; Tanoue, S.; et al. HGF-MET Signaling Shifts M1 Macrophages Toward an M2-Like Phenotype Through PI3K-Mediated Induction of Arginase-1 Expression. Fron. Immunol. 2020, 11. [CrossRef] [PubMed]

124. Garcia-Ocana, A.; Takane, K.K.; Syed, M.A.; Philbrick, W.M.; Vasavada, R.C.; Stewart, A.F. Hepatocyte growth factor overexpression in the islet of transgenic mice increases beta cell proliferation, enhances islet mass, and induces mild hypoglycemia. J. Biol. Chem. 2000, 275, 1226-1232. [CrossRef] [PubMed] 
125. Alvarez-Perez, J.C.; Ernst, S.; Demirci, C.; Casinelli, G.P.; Mellado-Gil, J.M.D.; Rausell-Palamos, F.; Vasavada, R.C.; Garcia-Ocana, A. Hepatocyte Growth Factor/c-Met Signaling Is Required for beta-Cell Regeneration. Diabetes 2014, 63, 216-223. [CrossRef] [PubMed]

126. Nackiewicz, D.; Dan, M.X.; Speck, M.; Chow, S.Z.; Chen, Y.C.; Pospisilik, J.A.; Verchere, C.B.; Ehses, J.A. Islet Macrophages Shift to a Reparative State following Pancreatic Beta-Cell Death and Area Major Source of Islet Insulin-like Growth Factor-1. Iscience 2020, 23. [CrossRef]

127. Kaminski, A.; Kaminski, E.R.; Morgan, N.G. Pre-incubation with interleukin-4 mediates a direct protective effect against the loss of pancreatic beta-cell viability induced by proinflammatory cytokines. Clin. Exp. Immunol. 2007, 148, 583-588. [CrossRef]

128. Souza, K.L.A.; Gurgul-Convey, E.; Elsner, M.; Lenzen, S. Interaction between pro-inflammatory and anti-inflammatory cytokines in insulin-producing cells. J. Endocrinol. 2008, 197, 139-150. [CrossRef]

129. Pfleger, C.; Meierhoff, G.; Kolb, H.; Schloot, N.C.; Grp, P.S. Association of T-cell reactivity with beta-cell function in recent onset type 1 diabetes patients. J. Autoimmun. 2010, 34, 127-135. [CrossRef]

130. Weitz, J.R.; Jacques-Silva, C.; Qadir, M.M.F.; Umland, O.; Pereira, E.; Qureshi, F.; Tamayo, A.; Dominguez-Bendala, J.; Rodriguez-Diaz, R.; Almaca, J.; et al. Secretory Functions of Macrophages in the Human Pancreatic Islet Are Regulated by Endogenous Purinergic Signaling. Diabetes 2020, 69, 1206-1218. [CrossRef]

131. Fu, W.; Farache, J.; Clardy, S.M.; Hattori, K.; Mander, P.; Lee, K.; Rioja, I.; Weissleder, R.; Prinjha, R.K.; Benoist, C.; et al. Epigenetic modulation of type-1 diabetes via a dual effect on pancreatic macrophages and beta cells. eLife 2014, 3, e04631. [CrossRef] [PubMed]

132. Parsa, R.; Andresen, P.; Gillett, A.; Mia, S.; Zhang, X.M.; Mayans, S.; Holmberg, D.; Harris, R.A. Adoptive transfer of immunomodulatory M2 macrophages prevents type 1 diabetes in NOD mice. Diabetes 2012, 61, 2881-2892. [CrossRef] [PubMed]

133. Zheng, D.; Wang, Y.; Cao, Q.; Lee, V.W.; Zheng, G.; Sun, Y.; Tan, T.K.; Wang, Y.; Alexander, S.I.; Harris, D.C. Transfused macrophages ameliorate pancreatic and renal injury in murine diabetes mellitus. Nephron. Exp. Nephrol. 2011, 118, e87-e99. [CrossRef] [PubMed]

Publisher's Note: MDPI stays neutral with regard to jurisdictional claims in published maps and institutional affiliations.

(C) 2020 by the authors. Licensee MDPI, Basel, Switzerland. This article is an open access article distributed under the terms and conditions of the Creative Commons Attribution (CC BY) license (http://creativecommons.org/licenses/by/4.0/). 